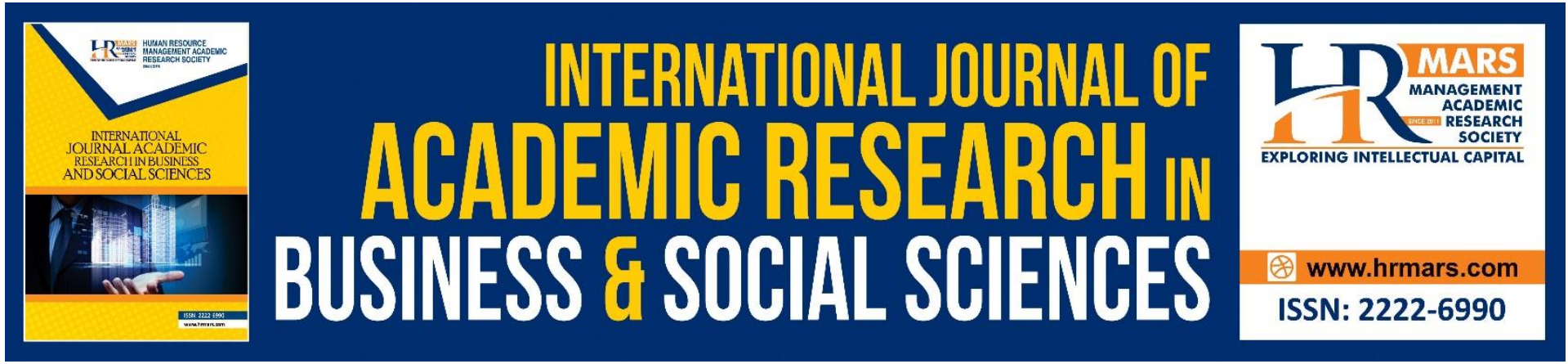

\title{
The Use of Imported CEFR-aligned English Language Textbooks in Malaysian Schools: Issues and Concerns
}

Mohamad Syafiq Ya Shak, Intan Safinas Mohd Ariff Albakri, Mohd Haniff Mohd Tahir, Mohd Hafiz Mat Adam

To Link this Article: http://dx.doi.org/10.6007/IJARBSS/v11-i9/10875

DOI:10.6007/IJARBSS/v11-i9/10875

Received: 03 July 2021, Revised: 01 August 2021, Accepted: 22 August 2021

Published Online: 14 September 2021

In-Text Citation: (Shak et al., 2021)

To Cite this Article: Shak, M. S. Y., Albakri, I. S. M. A., Tahir, M. H. M., \& Adam, M. H. M. (2021). The Use of Imported CEFR-aligned English Language Textbooks in Malaysian Schools: Issues and Concerns. International Journal of Academic Research in Business and Social Sciences, 11(9), 954-963.

Copyright: @ 2021 The Author(s)

Published by Human Resource Management Academic Research Society (www.hrmars.com)

This article is published under the Creative Commons Attribution (CC BY 4.0) license. Anyone may reproduce, distribute, translate and create derivative works of this article (for both commercial and non-commercial purposes), subject to full attribution to the original publication and authors. The full terms of this license may be seen at: http://creativecommons.org/licences/by/4.0/legalcode

Vol. 11, No. 9, 2021, Pg. 954 - 963

Full Terms \& Conditions of access and use can be found at http://hrmars.com/index.php/pages/detail/publication-ethics 


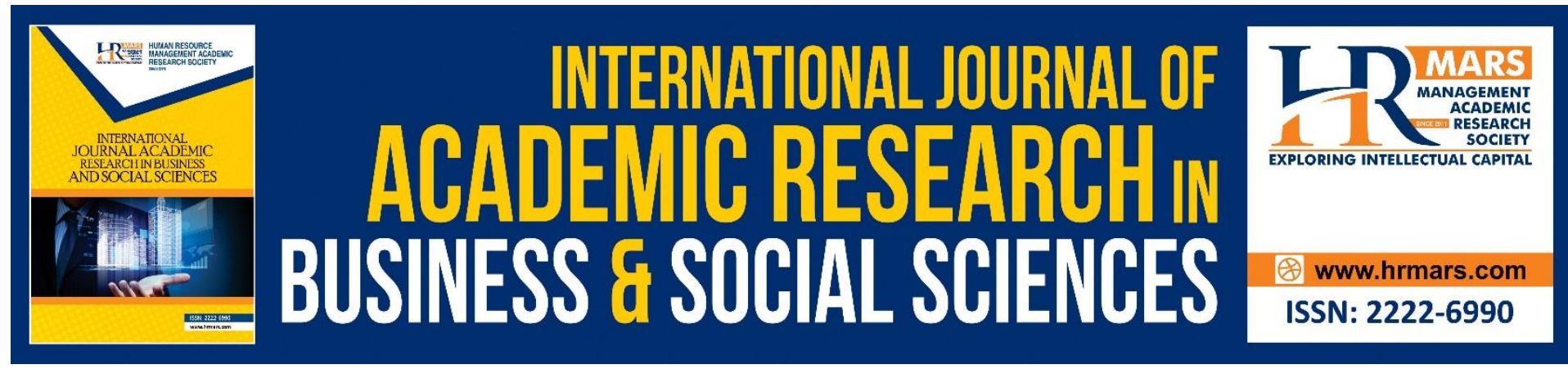

\title{
The Use of Imported CEFR-aligned English Language Textbooks in Malaysian Schools: Issues and Concerns
}

\author{
Mohamad Syafiq Ya Shak ${ }^{1,2}$, Intan Safinas Mohd Ariff Albakri², \\ Mohd Haniff Mohd Tahir ${ }^{2}$, Mohd Hafiz Mat Adam ${ }^{1}$ \\ ${ }^{1}$ Academy of Language Studies, Universiti Teknologi MARA Perak Branch, Perak, Malaysia. \\ ${ }^{2}$ Faculty of Languages \& Communication, Universiti Pendidikan Sultan Idris, Tg Malim, Perak, \\ Malaysia \\ Email: syafiq.yashak85@gmail.com
}

\begin{abstract}
Imported English language textbooks were introduced in Malaysian schools as part of the Common European Framework Reference of Language (CEFR)'s roll-out in this country through the establishment of the Standards Based English Language Curriculum (SBELC), which is the official English language curriculum in Malaysia. However, concerns were raised with regards to the use of these textbooks. Despite advocates clamoring for the textbooks' alignment to the CEFR and their contents, critiques were quick to point out their imbalanced cultural content, high lexical density, lack of supplementary materials, steep price point, ambiguous selection procedure, and fitness with the goals and objective of Malaysia's language program and English curriculum. Doubts were also expressed about Malaysian English teachers' preparedness to teach by using these books. It is then suggested that English language textbooks' selection procedure in Malaysia to be refined through the establishment of a systematic and transparent textbook evaluation framework. This will help in streamlining future English language textbooks selection and development processes in Malaysia while preventing any unnecessary outcry in future.
\end{abstract}

Keywords: CEFR, Get Smart, Imported Textbook, PULSE 2, Super Minds.

\section{Introduction}

Pre 2015, English language education in Malaysia operated as separate entities with little or no continuation between its different levels. It also does not offer a systematic approach from the preschool to tertiary levels. Because of this, the Common European Framework of References for Languages (CEFR) has been adopted as a basis to review the English Language curriculum in Malaysia. The revised curriculum, called Standards-Based English Language Curriculum (SBELC) is now CEFR-aligned and contextualized in Malaysia. It was rewritten by using descriptors found in the CEFR related documents, which is helpful for teachers, parents, and learners to understand what learners should be able to do at each level and for educators to pitch their teaching and learning sessions accordingly. It does not work on its own anymore; it is now part of a whole, integrated, and systematic approach to English Language learning. 
With the introduction of the CEFR-aligned English Language curriculum, adjustments are required in many aspects across the English language teaching spectrum in Malaysia and these include its teaching materials. The MOE has prescribed imported CEFR-aligned English textbooks to be used as the main teaching material in Malaysian schools. Titles introduced for this purpose are 'Super Minds' (Year 1 and 2), 'Get Smart Plus 3' (Year 3), 'Get Smart Plus 4' (Year 4), 'English Plus 1' (Year 5), 'Pulse 2' (Form 1 and 2), 'Close-up B1' (Form 3), 'Full Blast' (Form 4)' and 'English Dictionary' (Form 5).

The reactions towards the use of these textbooks have been mixed. The measure is welcomed by a segment of educators due to three reasons. The first reason is the nation' inability to produce textbooks that meet the new CEFR levels (Chin \& Rajaendram, 2017). At that time, CEFR was just introduced in Malaysia, and local book publishers were still struggling to publish an English textbook that could encapsulate the spirit of CEFR in such a short period of time after its roll out. Aziz (2017) seemed to agree with this notion as she reiterated the stand of the English Language Standards and Quality Council of Malaysia (ELSOQ) which stressed on the importance of getting quality CEFR-aligned textbooks especially at the initial phase of The Roadmap of English Language Education Reform in Malaysia while experts are identified, and expertise is developed to produce future local textbooks that are fit for Malaysian students. $P$ Kamalanathan, the then Education Ministry of Malaysia further defended the use of these textbooks as the Ministry strived to "ensure students achieve proficiency levels aligned to international standards" (Chin \& Rajaendram, 2017, p.2).

The second reason is to provide exposure to a higher level of English to local students (Ariz, 2017a). Such a move could boost local students' English proficiency since it is assumed that "the standards of the current local textbooks were too low, which prevented students from reaching a higher level of learning" (2017a, p.2). In addition, the use of higher level of English in imported textbooks could promote acceptance of other cultures and broadening one's viewpoint in aspects like culture, religion, and lifestyle (Ariz, 2017a). This could be attributed to the greater variety of culture content offered by these textbooks which tend to encourage the students to think and immerse in the said content as a 'citizen of the world'.

The third reason could be attributed to the content of these imported textbooks. The content is deemed as more current and cost-efficient (Chin \& Rajaendram, 2017). It is claimed that "schools can have new textbooks every year or every few years, unlike the current practice where the textbooks are only replaced when there is a change in syllabus" $(2017$, p.3). This is crucial because as mentioned in Chin \& Rajaendram (2017), the syllabus is not changed every often, therefore current issues are also not being properly dealt with and responded to in locally produced textbooks. They later added that changing textbooks too often will also incur unnecessary costs which are not productive in a situation where even the budget in school is tightly controlled and scrutinized. Hadi and Shah (2020) also reported that teachers seemed to be in favor with the content of these textbooks, as they can "provide an ample amount of activities and practices that can maximize the language learning in the classroom..... [and] adequate language skill practices that suit learners' need" $(2020$, p.78).

\section{Issues Surrounding the use of Imported English Language Textbook in Malaysia}

Inevitably, when a change is introduced, doubts will ensue. The same went to the roll out of these textbooks in Malaysian schools. The backlash was swift. Parents groups, teachers, 
academicians, and policy makers all piled on in raising their concerns about this textbook with regards to its imbalanced cultural content, high lexical density, lack of supplementary materials, steep price, ambiguous selection procedure, and fitness with the goals and objective of Malaysia's language program English curriculum. Questions were also raised about Malaysian English teachers' preparedness to teach English by using these books.

\section{Imbalanced Cultural Content}

With regards to its content, imported English language textbooks are deemed as irrelevant to local English learners due to their imbalanced and mismatched cultural content (Sabbiri, 2019; Din \& Yamat, 2020; Hadi \& Shah, 2020; Nazari \& Aziz, 2020; Takal et al., 2021). Rahim and Daghigh (2019) who analyzed the cultural content of English textbooks in Malaysia found out that 'PULSE 2' textbook offers zero content that relates to the Malaysian culture. This is a huge departure from the previously used English textbook for Form 1 students in Malaysia, 'English Form 1', where almost two-third of its contents focus on the local culture. Nazari and Aziz (2020) also shared similar findings, as they discovered that the proportion of culture contents are treated unequally in 'PULSE 2 ' and its "types of genre and cultural spectrum are arguably limited" (2020, p.87). Even the students who used this textbook indicated that the local culture is not given emphasis in the textbook (James \& Aziz, 2020).

Perhaps, this matter could be traced back to the fact that textbooks such as 'PULSE 2 ' is intended for Spanish-speaking English language learners and it was decided that it was best to simply adopt the textbook instead of adapting it to suit the local culture, in line with the rolling out of the CEFR in the country at that time. This matter could then present challenges to both the students and the teachers who are using these textbooks. The students might be having a hard time in comprehending the textbooks' content due to cultural barriers and they might "find it hard to relate to [the textbooks], especially [those who] are based in rural to sub urban backgrounds as they lack in curiosity" (Sabbiri, 2019, p.41).

The situation is not any easier for the teachers too, as they are struggling in establishing the connection between the language and the culture content to their students' lives. (Nazari \& Aziz, 2020). Not only that, but some parties fear that the nation is doing a great disservice to children who are using these imported textbooks, as "Malaysia has its own brand of English that is used by speakers with their own cultural values, pragmatic norms, and world views" (Marlina, 2017, p. 2).

\section{High Lexical Density}

The language content of these textbooks is also questioned. Takal et al (2021) for instance indicated that 'Get Smart Plus 3' textbook which is being used by Year Three students uses "difficult words in grammar explanations [and has] lack of sentence and paragraph structures in the writing part" (2021, p.727). Moreover, Sabbiri (2019) reported that teachers are experiencing difficulties in using 'Close-up B1' textbook for their Form Three students as it is "very difficult for the weaker classes" (2019, p.39). Furthermore, Din and Yamat (2020) implied that the vocabulary level in 'Super Minds' textbook is "high, [and] it is not suitable for student-centered [learning]" (2020, p.131), which is central to the implementation of the SBELC in Malaysia. 
'Pulse 2' textbook which is used by Form 1 and Form 2 students also suffers from this issue. Johar and Aziz (2019) for example indicated that "the lexical density [in the textbook] might be pretty high for the rural students" (p.5), and teachers might need to supplement the textbook "with other additional materials to connect this type of students to the input that is going to be taught" (p.9). Additionally, Goh and Aziz (2020) discovered that $46 \%$ of the surveyed English teachers who used PULSE 2 disagreed that the Speaking activities in the textbook use language that is at the right level of their pupils' current English ability. And more recently, Ya Shak et al. (2021) reported that some teachers felt that the grammar level in PULSE 2 could be challenging and unsuitable for the learners unless the learners aspire to become an English teacher later. Likewise, some parts of the textbook were also believed to be too difficult, while the others were deemed as too easy. It is then feared that this situation might greatly affect learners with low English Language proficiency who will need to comprehend the cultural context and the language being presented in the textbook simultaneously (Hammim, 2017; "Let's have our own textbooks", 2018).

\section{Lack of Supplementary Materials}

There are also issues about the lack of digital supplementary materials offered by these imported textbooks. "How will teachers" (2017) disclosed that 'Pulse 2' textbook for example does not come with individual sets of CDs or an easier means to for the students to access it. It also fails to offer additional online supplementary materials through a companion website or a mobile application. To worsen the situation, it was also claimed that each school only received two set of Audio CDs to be used by all the Form 1 and Form 2 students at that school.

On the contrary, the 'English Form 1' textbook which was used previously and produced locally, offered opportunities for its users to access online supplementary materials simply by scanning a QR code on the textbook. 'English Form 1' also offered a mobile application to accompany the textbook. A lack of supplementary materials "effectively means that the textbooks are of little use other than during lessons in the classroom" ("How will teachers", 2017, p.1), while denying "the importance of a good ELT textbook that can provide additional materials and resources that would support teaching and learning" (Roberts et al., 2020b, p.7437).

\section{Steep Price Point}

Since imported textbooks such as 'Pulse 2' does not offer sufficient supplementary materials, the price point of these textbooks has also become another point of contention. As indicated in 'Teachers are not trained properly' (2017), the assemblyman of Bukit Bendera, Zairil Khir Johari, who was also a Parliamentary Spokesperson for Education, Science, and Technology excoriated the price of "PULSE 2" which is set at a steep RM38 (USD 9) per copy, which costs about five times more expensive than the locally produced English textbook for secondary students called 'English Form 1' by Penerbitan Pelangi which was priced at a meagre RM7.50 (USD1.70) a copy. He considered this high price as unjustified, given the fact that the imported textbook was printed locally, and its lack of supplementary materials, which will ultimately put another burden on the already bloated government budget as textbooks are provided for free for all Malaysian students. 


\section{Ambiguous Selection Procedure}

Johari (2017) questioned the method of selecting these imported textbooks. He urged the Ministry of Education to reveal the identity of the "English Language Experts" who approved the foreign textbooks and the "selection panel" who selected these experts. He then insinuated that these experts might not have vetted the content properly, since "they approved of not only the totally foreign references contained in the books, but even the exercise questions that require basic knowledge of Spanish" (2017, p.1). He also implied that no real selection process had taken place in reality and the so-called 'selection process' which was clouded with secrecy was only a lame attempt to justify the absence of a more open and transparent book procurement system. He later warned that "while efforts to improve English proficiency among our students and teachers must be supported, it does not mean that the education ministry can do whatever it likes, and worse, risk the future of our children through irresponsible experimenting and ill-advised policy decisions." ('Why weren't imported textbooks', 2017, p.2).

Fitness with the goals and objective so Malaysia's language program and English curriculum There were also concerns about the fitness of the imported textbooks with the goals and the objectives of Malaysia's language program and English curriculum. Din and Yamat (2020) investigated the challenges that teachers faced in using 'Super Minds', the imported textbook for Year 1 and 2 students. They disclosed that about two-thirds of the teachers believed that 'Super Minds' does not support the goals and objectives of the program and the curriculum. This might bear an impact on the students' abilities in achieving the objective of the program, and the "creation of the country's version of the Common European Framework of Reference for Languages (CEFR) called 'CEFR-M' as projected in the on-going English Language Education Reform in Malaysia by 2025" (Ya Shak et al., 2021, p.177).

\section{Teachers' Preparedness in Using Imported English Language Textbooks}

It is mentioned that "one of the consequences of aligning our English language programme with the CEFR is that we have to ensure that our English teaching practices are fit for purpose (Dom, 2016, p.1)". Questions were raised on the preparedness of Malaysian English teachers who will be using these imported texts. The Melaka Action Group for Parents (MAGPIE) through its chairman, Mak Chee Kin, for example claimed that many teachers were worried and feeling stressed about teaching their students properly with 'Pulse 2' because they were not properly trained to handle the book ('Teachers are not trained', 2017). His concern is not without basis. He stated that only one teacher per school was sent for training, allegedly due to budget constraints, and this this teacher was required to train other English teachers at his or her establishment. To worsen the matter, he asserted that this this teacher could only get $80 \%$ of the knowledge from such training at best, and this will have further repercussions on the amount of knowledge other English teachers will receive at his or her establishment.

Not only that, Parent Action Group for Education (PAGE), which earlier hailed the decision of using off-the-shelf textbooks for Malaysian students (Ariz, 2017a; Chow, 2017) mirrored the same position, as they were puzzled as to whether teachers know how to teach the new syllabus by using the new imported textbooks or not (Ariz, 2017b). Its Head, Noor Azimah Rahim later urged "the ministry to be efficient in allowing the teachers to be "upskilled" for the purpose [of using imported textbooks]" (Ariz, 2017a, p.2) and to "be accountable for 
ensuring teachers are capable of guiding students to use the new textbooks" (Ariz, 2017b, p.1).

\section{Discussion}

One of the immediate implications of the issues surrounding the use of imported English language textbooks in Malaysia is the call for a better approach in evaluating and selecting English language textbooks in Malaysia. It should be done within a framework that is standardized, systematic, and puts the local context at its center. Attempts in evaluating English language textbooks in Malaysia are scarce, as schools use textbooks which are assigned by the Ministry of Education Malaysia (MOE). Attempts to do so additionally were not done in a standardized and systematic manners since they did not utilize a textbook evaluation framework that offers a similar set of criteria or procedures. The criteria and procedures in such frameworks also were not developed with the local context in mind (Mukundan, 2004; Ahmed, 2016; Momand et. al., 2019; Roberts et al., 2020), as these frameworks were established by foreign English language textbook evaluators.

The issues also highlight the need for an English language textbook evaluation framework that aligns with the local curriculum, in this case, the Standards Based English Language Curriculum (SBELC), which is based on the CEFR. Mukundan and Nimehchisalem (2012) had in a way attempted to do this, by developing a local English textbook evaluation framework which employed the use of a checklist. It was used by at least one study by Khoo and Knight (2015) to evaluate an English language textbook. However, based on the elements in the said framework, it was not immediately clear how the fitness of a textbook's contents with the local curriculum at that time (Malaysian Integrated Curriculum for Secondary Schools - KBSM and Malaysian Integrated Curriculum for Primary Schools - KBSR) can be evaluated. Not only that, the elements of this framework are also not aligned to the elements of the current SBELC and the CEFR since it was developed before these curriculum frameworks were introduced in Malaysian schools. At the same time, it is also not intended to exclusively evaluate CEFRaligned English Language textbooks or materials. Because of these dissimilarities and a lack of contextualization, Roberts et al (2020a) warn that the previously used textbook evaluation frameworks might have its own issues and weaknesses and are inadequate in serving and catering to the learners' needs and the language program they attend.

\section{Conclusion}

There are always two sides to an argument, and the arguments on the use of imported English language textbooks in Malaysian schools are no exception. Majority of the studies on this measure indicated that teachers mostly welcome the use of these textbooks in their language classes. However, they still have reservations about them, as discussed earlier. Undoubtedly there will always be rooms for improvements and these textbooks can be enhanced in some parts. It could start through a transparent and systematic textbook selection framework that is developed locally, which could highlight the strengths and weaknesses of an English textbook (Wong, 2011; Wuttisrisiriporn \& Usaha, 2019). It is believed that such a framework will enable teachers to identify the areas of the textbook that need to be modified and the extent to which adaptation and development of additional teaching materials is necessary (Wong, 2011). It is then hoped that this study will benefit all the relevant stakeholders in the Malaysian education system to streamline the process of English language textbook selection and development while preventing any unnecessary outcry in future. 


\section{References}

Abdelwahab, M. M. (2013). Developing an English Language textbook evaluative checklist. IOSR Journal of Research \& Method in Education, 1(3), 55-70.

Ahmed, M., Yaqoob, H., \& Yaqoob, M. (2015). Evaluation of listening skill of ELT textbook at secondary school level. Advances in Language and Literary Studies, 6(3), 225-229.

Ariz, N. A. (2017a). Free Malaysia Today. Imported English textbooks will boost students' proficiency. Retrieved from https://www.freemalaysiatoday.com/category/nation/2017/10/07/importedenglish-textbooks-will-boost-students-proficiency/.

Ariz, N. A. (2017b). Free Malaysia Today. New books: English Teachers must know what to teach. Retrieved from https://www.freemalaysiatoday.com/category/nation/2017/12/12/new-booksenglish-teachers-must-know-what-to-teach-says-page/.

Aziz, H. (2017). New Straits Times. Textbook do not make the teachers. Retrieved from https://www.nst.com.my/opinion/columnists/2017/12/311230/textbooks-do-notmake-teacher

Chin, C., Rajaendram, R. (2017). The Star. Only imported English textbooks from next year. Retrieved from https://www.thestar.com.my/news/nation/2017/10/05/onlyimported-english-textbooks-from-next-year-move-part-of-reform-to-ensureinternational- proficient.

Chow, M. D. (2017). Free Malaysia Today. Academic calls for localized English texts. Retrieved from https://www.freemalaysiatoday.com/category/nation /2017/10/11/academic-calls-for-localised-english-texts/.

Din, F. F. M., \& Yamat, H. (2020). Challenges faced by teachers in using Supermind textbook. International Journal of Academic Research in Progressive Education and Development, 9(1), 122-133.

Dom, Z. M. (2016). New Straits Times. Communicative approach. Retrieved from https://www.nst.com.my/news/2017/03/196760/communicative-approach.

Goh, Y. T., \& Aziz, A. A. (2020). Using PULSE 2 to teach and assess Malaysian pupils' speaking skill. International Journal of Publications and Social Studies, 5(1), 55-68.

Hadi, M. L. A., \& Shah, P. M. (2020). Malaysian ESL teachers' Perception towards CEFR-aligned textbooks. International Journal of New Technology and Research, 6(10), 73-79.

Hammim, R. (2018). New Straits Times. JELTA wants Education Ministry to rethink used of imported textbooks. Retrieved from

https://www.nst.com.my/news/nation/2018/01/322975/jelta-wants-educationministry-rethink-use-imported-textbooks.

James, P. R., \& Aziz, A. A. (2020). Perceptions and expectancies of Malaysian students on cultural elements in foreign textbooks. International Journal of Academic Research in Business and Social Sciences, 10(4), 214-231.

Johar, N. A., \& Aziz, A. A. (2019). Teacher's perceptions on using the PULSE 2 textbook. Journal of Educational Research and Indigenous Studies, 2(1), 1-15.

Johari, Z. K. (2017). MOE's reply raises more questions than answers about "imported" English textbooks. [Press Release]. Retrieved from https://dapmalaysia.org/statements/2017/12/03/26208/. 
Khoo, H. S., \& Knight, P. (2015). Teachers' evaluation of KBSM Form 4, 5 English textbooks used in the secondary schools in Penang, Malaysia. Advances in Language and Literary Studies, 6(4), 128-150.

Let's have our own textbooks. (2018). The Star. Retrieved from https://www.thestar.com.my/news/education/2018/02/04/lets-have-our-owntextbooks/.

Marlina, R. (2017). Teaching English as an international language: Implementing, Reviewing, and re-envisioning world Englishes in language education. Routledge.

McGrath, I. (2016). Materials evaluation and design for language teaching (2nd ed). Edinburgh University Press.

Momand, M., Sugunabalan, A., Ibrahim, S. A. M., \& Sandaran, S. (2019). An evaluation of Primary Year 6 (KSSR) English textbook. International Journal of Engineering and Advanced Technology, 8 (5C), 1192 -1199.

Mukundan, J. (2004). ESL textbook evaluation: A composite framework. Lambert Academic Publishing.

Mukundan, J., \& Nimehchisalem, V. (2012). Evaluative criteria of an English Language textbook evaluation checklist. Journal of Teaching and Research, 3 (6), 1128 -1134.

Nazari, W. A. A. W., \& Aziz, A. A. (2020). Content analysis of PULSE 2 textbook's reading texts. International Journal of Applied Science and Engineering Review, 1(6), 68-90.

Rahim, H. A., \& Daghigh, A. J. (2019). Locally developed versus global textbooks: An evaluation of cultural content in textbooks used in English language teaching in Malaysia. Asian Englishes, DOI: 10.1080/13488678.2019.1669301.

Richards, J. C. (2016). Curriculum development in language teaching (2nd Ed.). Cambridge University Press.

Roberts, F., Aziz, A. A., \& Matore, M. E. E. M. (2020a). Malaysian teachers' perception on Cambridge English textbook evaluation checklist for materials adaptation: A preliminary study. International Journal of Advanced Science and Technology, 29(3), 2020- 2030.

Roberts, F., Aziz, A. A., \& Matore, M. E. E. M. (2020b). Criteria of a good ELT textbook: Malaysian teachers' perception. Universal Journal of Educational Research, 8(12A), 7433 - 7442. DOI:10.13189/ujer.2020.082527.

Sabbiri, F. (2017). Perceived view of teachers towards Pentaksiran Tingkatan Tiga (PT3) (Form Three Assessment) English Language: A case study. Asian Journal of University Education, 15(3), 34 - 44.

Takal, G. M., Planisamay, T., Gani, N. A. I., Peter, C. V., \& Singh, P. M. K. (2021). An evaluation of 'Get Smart' English language textbook from the perspectives of English teachers. AKSARA: Jurnal IImu Pendidikan Nasional, 7(2), 727-746.

Teachers not trained properly to use English textbooks, says parents' group. (2017). Free Malaysia Today. Retrieved from https://www.freemalaysiatoday.com/category/nation/2017/12/03/teachers-nottrained-properly-to-use-imported-english-textbooks-says-parents-group/.

Why weren't imported textbooks purchased through open tender?. (2017). Free Malaysia Today. Retrieved from https://www.freemalaysiatoday.com/category/nation/2017/11/25/why-werentimported-textbooks-purchased-through-open-tender. 
Wong, L. P. W. (2011). Textbook evaluation: A framework for evaluating the fitness of the Hong Kong New Secondary School (NSS) curriculum (Unpublished Master Dissertation). City University of Hong Kong, China.

Wuttisrisiripon, N., \& Usaha, S. (2019). The development of a localized ELT textbook evaluation checklist: A case study from Thailand. Thai TESOL Journal, 32 (2), 46 -64.

Ya Shak, M. S., Malik, N. A., Hasni, N. A., \& Tahir, M. H. (2021). Revisiting PULSE 2 Textbook after three years: Have teachers changed their mind?. Malaysian Journal of Social Sciences and Humanities, 6(5), 177-189. DOI:

https://doi.org/10.47405/mjssh.v6i5.777. 